\title{
Use of Yeast-Fermented Canola Meal to Replace Fishmeal in the Diet of Asian Sea Bass Lates Calcarifer (Bloch, 1790)
}

\section{Pichet Plaipetch and Amararatne Yakupitiyage*}

Aquaculture and Aquatic Resources Management Program, School of Environment and Resources Development, Asian Institute of Technology, P. O. Box 4, Klong Luang, Pathum Thani 12120, Thailand

\begin{abstract}
Fishmeal is a significant protein source for aquatic feed, especially for carnivorous fish. Currently, the price of fishmeal is increasing, also it is mentioned as a competition of human food fish. Replacing fishmeal by other protein sources is therefore an important target. This study tested yeast-fermented canola meal in the diet of Asian sea bass, Lates calcarifer to determine its effects on growth, feed acceptance, feed utilization, nutrient digestibility, body proximate, minerals and their utilization. Diets consisted of a 35\% fishmeal base (control) and four diets in which fishmeal protein was replaced by yeast-fermented canola meal at levels of $25,50,75$ and $100 \%$. For each diet, three groups of fish with an initial weight of $5 \mathrm{~g}$ were fed to satiation twice a day for 60 days.

Feed intakes and survival rates of test fish fed the diets with up to $50 \%$ replacement were not significantly different $(P>0.05)$. Fish fed the diet with $100 \%$ replacement rejected the feed and all died within two weeks. Fish fed the diet in which $75 \%$ of fishmeal protein replacement had lower final mean weight, daily weight gain, protein efficiency ratio, nutrient digestibility and higher feed conversion ratio $(P<0.01)$ than fish fed the control, $25 \%$ and $50 \%$ replacement diets. Increasing the protein replacement level lowered body crude protein, ash, Ca, Mg, P and their utilization of Asian sea bass $(P<0.05)$. This seemed to relate to increasing dietary phytic acid as the inclusion level of yeast-fermented canola meal increased. It was concluded that $50 \%$ of fishmeal in the diet of Asian sea bass could be replaced by yeast-fermented canola meal without overall impact on growth. This study also showed the possibility of $<10 \%$ dietary fishmeal for this species since fish accepted a diet containing only $8.75 \%$ fishmeal.
\end{abstract}

Keywords: Asian sea bass; Diet; Fishmeal; Yeast-fermented canola meal

\section{Introduction}

Asian sea bass, Lates calcarifer (Bloch, 1790) is an economically farmed species in Indo-Pacific waters such as Southeast Asian countries, Taiwan and Australia [1]. It is also popular in the US [2]. Culture of this species is heavily dependent on the use of marine trash fish as the main feed. However, the price of trash fish has increased due to the lower volume caught. This reduces the benefit of farming and makes culture in this way unsustainable. To solve this problem, the use of commercial feed has been promoted [3]. Unfortunately, Asian sea bass feed contains approximately $20-50 \%$ fishmeal [4]. It results in a rather high price for Asian sea bass due to the high fishmeal price. This means that changing from using marine trash fish to commercial feed in Southeast Asian countries is slow. Hence, it is necessary to reduce the use of dietary fishmeal for this species, and for other farmed carnivorous fish. Furthermore, reduction in the use of both marine trash fish and dietary fishmeal may reduce concerns about competition with fish use for human food [5]. Actually, unmarketable size of food fish can be caught along with trash fish, thereby depleting stocks.

To reduce the need for dietary fishmeal in Asian sea bass feed, several alternative protein sources are being investigated [6]. For example, meals of soybean, canola, lupin and rendered meat have been tested $[7,8]$. Among them, canola meal is an interesting candidate due to its cheaper price compared with fishmeal and its high availability, second after soybean meal [9]. However, a high level of dietary canola meal may affect fish growth because of the high amounts and various types of anti-nutritional factors (ANF), such as phytic acid [10].

To reduce the level of ANF and other adverse factors in canola meal, protein isolation can be useful but the price of the product is uncompetitive relative to fishmeal [6]. A cheap method of yeast fermentation combined with water soaking may be an alternative way to improve the nutritional value of canola meal. Reducing phytic acid by yeast fermentation has been reported previously [11,12]. Meanwhile, water soaking facilitates to eliminate derivatives of glucosinolate, phytic acid, tannins and oligosaccharides $[13,14]$.

Currently, there is no available information on the use of yeastfermented canola meal to replace fishmeal in the diet of Asian sea bass. The aim of this study was to determine the effect of replacing fishmeal by yeast-fermented canola meal on growth, feed utilization, body proximate, minerals and their utilization in this species. Feed acceptance was also a main point to evaluate; use of a plant protein source at a high level may lead to lower feed acceptance [15].

\section{Materials and Methods}

\section{Preparation of yeast-fermented canola meal}

Canola meal was purchased from Sor Chareonpanich Co. Ltd., Samut Prakan, Thailand, and ground to a particle size of $<500 \mu \mathrm{m}$ by means of a hammer mill. Five replicate fermentations were performed by a modification of a method used in a previous study [16]. For each repli-

${ }^{*}$ Corresponding author: Amararatne Yakupitiyage, Aquaculture and Aquatic Resources Management Program, School of Environment and Resources Development, Asian Institute of Technology, P. O. Box 4, Klong Luang, Pathum Thani 12120, Thailand, Tel: (+662) 524-5456; Fax: (+662) 524-5400; E-mail: amara@ait.ac.th

Received February 18, 2012; Accepted March 16, 2012; Published March 28 2012

Citation: Plaipetch P, Yakupitiyage A (2012) Use of Yeast-Fermented Canola Meal to Replace Fishmeal in the Diet of Asian Sea Bass Lates Calcarifer (Bloch, 1790). J Aquac Res Development 3:125 doi:10.4172/2155-9546.1000125

Copyright: (c) 2012 Plaipetch P, et al. This is an open-access article distributed under the terms of the Creative Commons Attribution License, which permits unrestricted use, distribution, and reproduction in any medium, provided the original author and source are credited. 
cate, $2 \mathrm{~kg}$ of canola meal, $66.7 \mathrm{mg}$ of commercial dry yeast, Saccharomyces cerevisiae, with a cell density of $3 \times 10^{9}$ cell g$^{-1}$ (Fermipan ${ }^{\oplus}$, GB ingredients, the Netherlands) and $1.6 \mathrm{~L}$ of distilled water were homogenized in a Hobart food mixer for 15 minutes. This provided a yeast density of $1 \times 10^{5}$ cell g-1 meal and $50 \%$ moisture. Each replicate fermentation was conducted for 24 hours in a 10 litre glass jar covered with aluminium foil. Then, the fermented meal was soaked with $6 \mathrm{~L}$ of distilled water for 5 minutes. After decanting the excess water, a fine mesh cloth was used to squeeze the meal to remove as much water as possible and remove dissolved glucosinolate and its derivatives from the fermented meal [13]. The residual meal was dried to constant weight at $70^{\circ} \mathrm{C}$. The nutrient and phytic acid content of the yeast-fermented canola meal are shown in Table 1.

\begin{tabular}{|l|l|l|l|l|l|}
\hline & $\begin{array}{l}\text { Unfer- } \\
\text { mented }\end{array}$ & $\begin{array}{l}\text { Yeast fer- } \\
\text { mented }\end{array}$ & & Unfermented & $\begin{array}{l}\text { Yeast fer- } \\
\text { mented }\end{array}$ \\
\hline Crude protein & $386.7 \pm 1.3$ & $422.5 \pm 2.1$ & Threonine & \\
** & $7.73 \pm 0.06$ & $6.64 \pm 0.06$ \\
\hline Crude lipid & $30.1 \pm 1.2$ & $26.0 \pm 1.3$ & Valine & $4.33 \pm 0.05$ & $3.79 \pm 0.03$ \\
\hline Ash & $79.3 \pm 0.5$ & $78.4 \pm 0.3$ & Methionine & $2.62 \pm 0.02$ & $2.54 \pm 0.03$ \\
\hline $\mathrm{Ca}$ & $8.1 \pm 0.3$ & $9.4 \pm 0.2$ & Isoleucine & $3.40 \pm 0.04$ & $2.87 \pm 0.05$ \\
\hline $\mathrm{Mg}$ & $7.3 \pm 0.2$ & $8.2 \pm 0.1$ & Leucine & $7.22 \pm 0.03$ & $6.42 \pm 0.03$ \\
\hline $\mathrm{P}$ & $12.8 \pm 0.3$ & $13.9 \pm 0.4$ & $\begin{array}{l}\text { Phenylala- } \\
\text { nine }\end{array}$ & $3.86 \pm 0.04$ & $3.37 \pm 0.06$ \\
\hline $\mathrm{Fe}\left(\mathrm{mg} \mathrm{Kg}^{-1}\right)$ & $354.2 \pm 10.8$ & $447.1 \pm 4.8$ & Lysine & $5.63 \pm 0.06$ & $3.90 \pm 0.04$ \\
\hline $\mathrm{Zn}\left(\mathrm{mg} \mathrm{Kg}^{-1}\right)$ & $44.4 \pm 1.3$ & $58.7 \pm 1.2$ & Histidine & $2.55 \pm 0.04$ & $2.32 \pm 0.05$ \\
\hline $\mathrm{Cu}\left(\mathrm{mg} \mathrm{Kg}^{-1}\right)$ & $4.5 \pm 0.1$ & $5.7 \pm 0.1$ & Arginine & $5.43 \pm 0.04$ & $4.28 \pm 0.02$ \\
\hline $\mathrm{Mn}\left(\mathrm{mg} \mathrm{Kg}^{-1}\right)$ & $64.7 \pm 1.9$ & $76.5 \pm 3.3$ & & & \\
\hline Phytic acid & $35.1 \pm 0.4$ & $28.9 \pm 0.4$ & & & \\
\hline $\begin{array}{l}\text { Phytic acid- } \\
\text { P } \dagger\end{array}$ & $9.9 \pm 0.1$ & $8.1 \pm 0.1$ & & & \\
\hline Available P $\dagger$ & $2.9 \pm 0.1$ & $5.8 \pm 0.1$ & & & \\
\hline
\end{tabular}

* Proximate $(n=5)$, minerals and essential amino acids $(n=3)$, $†$ calculated by dividing phytic acid

with 3.55 , Available phosphorus is calculated by differences of total phosphorus and phytic acid-P

** Trytophan is destroyed during sample preparation

Table 1: Nutrients and phytic acid of yeast fermented canola meal (g Kg-1, dry basis). *

\begin{tabular}{|c|c|c|c|c|c|}
\hline & \multicolumn{5}{|c|}{$\%$ Replacing fishmeal protein } \\
\hline & 0 & 25 & 50 & 75 & 100 \\
\hline $\begin{array}{l}\text { Yeast fermented canola } \\
\text { meal }\end{array}$ & - & 124.3 & 248.6 & 372.9 & 497.2 \\
\hline $\begin{array}{l}\text { Tuna-byproduct } \\
\text { fishmeal }\end{array}$ & 350.0 & 262.5 & 175.0 & 87.5 & - \\
\hline Shrimp head meal & 20.0 & 20.0 & 20.0 & 20.0 & 20.0 \\
\hline Squid liver meal & 100.0 & 100.0 & 100.0 & 100.0 & 100.0 \\
\hline Corn gluten & 120.0 & 125.0 & 133.0 & 140.0 & 148.0 \\
\hline Soybean meal & 50.0 & 50.0 & 50.0 & 50.0 & 50.0 \\
\hline Wheat flour & 156.0 & 120.8 & 73.5 & 46.9 & 9.0 \\
\hline Cellulose & 56.0 & 42.5 & 38.0 & 13.9 & - \\
\hline Tuna oil & 59.0 & 66.8 & 73.8 & 80.7 & 87.7 \\
\hline Soybean oil & 38.8 & 37.9 & 37.9 & 37.9 & 37.9 \\
\hline Antioxidant (BHT) & 0.2 & 0.2 & 0.2 & 0.2 & 0.2 \\
\hline Vitamin premix* & 10.0 & 10.0 & 10.0 & 10.0 & 10.0 \\
\hline Mineral premix $†$ & 30.0 & 30.0 & 30.0 & 30.0 & 30.0 \\
\hline Chromic oxide $\left(\mathrm{Cr}_{2} \mathrm{O}_{3}\right)$ & 10.0 & 10.0 & 10.0 & 10.0 & 10.0 \\
\hline
\end{tabular}

* Vitamin premix contains ( $\mathrm{g} \mathrm{Kg}^{-1}$ premix): vitamin A, 0.138; D, 0.002; E, 10; K, 5 $\mathrm{B}_{1}, 6 ; \mathrm{B}_{2}, 10 ; \mathrm{B}_{3}, 40 ; \mathrm{B}_{5}, 10 ; \mathrm{B}_{6}, 4 ; \mathrm{B}_{12}, 0.01$, p-amino benzoic acid, 5 ; folic acid, 1.5; biotin 0.6; inositol 200; choline chloride, 500 and vitamin $\mathrm{C}, 50 \mathrm{~g}$

† Mineral premix contains ( $\mathrm{g} \mathrm{Kg}^{-1}$ premix): $\mathrm{KCl}, 131.7 ; \mathrm{NaH}_{2} \mathrm{PO}_{4} .2 \mathrm{H}_{2} \mathrm{O}, 394.7$; CaH$\mathrm{PO}_{4}, 210.5$ and $\mathrm{KH}_{2} \mathrm{PO}_{4}, 263.1 \mathrm{~g}$

Table 2: Ingredients of the test diets for Asian sea bass ( $\mathrm{g} \mathrm{Kg}-1$ ).

\begin{tabular}{|l|l|l|l|l|l|}
\hline \multirow{2}{*}{} & \multicolumn{5}{l}{ \% Replacing fishmeal protein } \\
\cline { 2 - 5 } & 0 & 25 & 50 & 75 & 100 \\
\hline Proximate (wet basis) & & & & & \\
\hline Moisture & 72.90 & 66.90 & 69.80 & 68.50 & 70.90 \\
\hline Crude protein & 432.20 & 431.60 & 431.20 & 430.50 & 430.00 \\
\hline Crude lipid & 170.70 & 170.00 & 170.40 & 170.60 & 170.40 \\
\hline Ash & 128.00 & 120.50 & 116.10 & 110.50 & 104.80 \\
\hline Minerals & & & & & \\
\hline Ca & 42.07 & 40.69 & 39.15 & 38.22 & 37.05 \\
\hline Mg & 6.09 & 6.11 & 6.15 & 6.19 & 6.24 \\
\hline P & 20.42 & 19.9 & 19.38 & 18.87 & 18.15 \\
\hline Fe & 3.79 & 3.51 & 3.3 & 3.11 & 2.80 \\
\hline Zn & 0.31 & 0.35 & 0.37 & 0.38 & 0.40 \\
\hline Cu & 0.14 & 0.14 & 0.13 & 0.12 & 0.11 \\
\hline Mn & 0.37 & 0.34 & 0.31 & 0.27 & 0.24 \\
\hline Phytic acid & 2.80 & 5.90 & 9.00 & 12.30 & 15.10 \\
\hline Phytic acid-P* & 0.79 & 1.66 & 2.53 & 3.46 & 4.25 \\
\hline Available P† & 19.63 & 18.24 & 16.85 & 15.41 & 13.90 \\
\hline
\end{tabular}

* Calculated by dividing phytic acid with 3.55

† Calculated by differences of total phosphorus and phytic acid-P

Table 3: Proximate composition, minerals and dietary phytic acid of the test diets of Asian sea bass $\left(\mathrm{g} \mathrm{Kg}^{-1}\right.$, dry basis).

\section{Preparation of test diet}

Five isonitrogenous test diets were produced. One, the control diet, was a modification of a formulation used in a previous study [15], and contained 35\% fishmeal. In the other four diets, fishmeal protein was replaced by yeast-fermented canola meal at levels of $0,25,50,75$ and $100 \%$, respectively. Chromic oxide $\left(\mathrm{Cr}_{2} \mathrm{O}_{3}\right)$ was used as a marker to determine nutrient digestibility. Each diet, in batches of $1 \mathrm{~kg}$, was mixed with $30 \%$ water and formed into pellets by forcing through a mincing machine with $3 \mathrm{~mm}$ pore. All the test feeds were then dried overnight at $70^{\circ} \mathrm{C}$, broken into an optimum length of $3-5 \mathrm{~mm}$, stored in plastic bags and kept in a freezer at $-20^{\circ} \mathrm{C}$ until use. The ingredients of the test diets are shown in Table 2 and their proximate and mineral compositions and phytic acid content are shown in Table 3.

\section{Fish husbandry}

Groups of ten Asian sea bass fingerlings with an average body weight of $5 \mathrm{~g}$ were randomly distributed into each of fifteen $100 \mathrm{~L}$ fiberglass tanks. The tank base was connected with a fecal collection column similar to the model used in a previous study [17]. For each test diet, three groups of fish were fed twice a day (at 0900 and $1500 \mathrm{~h}$ ) to apparent satiation. Two hours before the first feeding (at $0700 \mathrm{~h}$ ), the fish tanks were cleaned and $25 \%$ of the water was exchanged to maintain good water quality.

Fish feces were collected twice a day after the first 7 days of feeding. During the collection time, the uneaten diet and any waste were removed from the fish tank at 1000 and 1600 h, i.e. an hour after each meal. Then, the feces in the column were collected (at 1300 and $1900 \mathrm{~h}$ ) by filtration through the filter paper, and kept in a freezer at $-20^{\circ} \mathrm{C}$. The collection was continued for 7 days. Fish feces from the same tank were pooled to provide sufficient fecal sample for chemical analysis.

During the 60 days of the trial, the fish from each tank were weighed together every 15 days. The diet consumed and the remaining numbers of fish were also recorded. At the end of the trial, three fish from each tank were sacrificed and dried to constant weight at $70^{\circ} \mathrm{C}$ before analysis of proximate and mineral composition. 


\section{Chemical analysis, calculations and data analysis}

Analysis of proximate composition followed the methods of AOAC [18]. Moisture was analyzed by drying at $100^{\circ} \mathrm{C}$ overnight. Crude protein and lipid were analyzed by means of a Kjeltec 2200 and a Soxtec 1043 (FOSS, Denmark), respectively. Ash content was analyzed by combustion of samples at $550^{\circ} \mathrm{C}$ overnight. An ICP-OES 2100 DV (Perkin Elmer, Waltham, MA, USA) was used to analyze minerals and chromium contents in diet and feces after nitric-perchloric acid treatment, by an AOAC method [19]. The amino acid profile after acid hydrolysis with $6 \mathrm{M} \mathrm{HCl}$ for 24 hours was determined by HPLC. An Agilent 1100 series (Agilent Technologies, Palo Alto, CA, USA) instrument was used. This study gave data for only nine essential amino acids, because tryptophan was destroyed during acid hydrolysis.

The phytic acid content was analyzed by a method [20] modified from that used in a previous study [21]. This method used $0.5 \mathrm{M} \mathrm{HNO}_{3}$ and $1 \% \mathrm{NH}_{4} \mathrm{SCN}$ instead of $0.5 \mathrm{M} \mathrm{HCl}$ and $10 \% \mathrm{KSCN}$. Phytic acid-P was calculated by dividing the phytic acid content by 3.55 [21].

This constant was ratio of molecular weights of phytic acid and six phosphorus atoms containing in phytic acid. Available phosphorus was calculated from the difference between total phosphorus and phytic acid-P [22].

Growth, feed and nutrient utilization were calculated by the following equations:

Mean weight $(\mathrm{g})=[$ total body weight/numbers of fish $]$

Daily weight gain $(\mathrm{g} \mathrm{d}-1)=[($ final - initial body weight $) /$ day $]$

Survival rate $(\%)=[100 \mathrm{x}($ final - initial numbers of fish $) /$ initial numbers of fish)]

Feed intake $(\%$ BW d-1) $=[100 \mathrm{x}$ (total dry diet consumed/mean of initial and final body weight)/day]

Feed conversion ratio $=[$ total dry diet consumed/weight gain $]$

Protein efficiency ratio $=[$ weight gain/protein consumed $]$

Nutrient utilization $(\%)=[100 \mathrm{x}($ final - initial body nutrient $) / \mathrm{nu}-$ trient consumed].

Dry matter and nutrient digestibility were calculated by the following equations [23]:

Dry matter digestibility $(\%)=100-[100 \times(\% \mathrm{Cr} 2 \mathrm{O} 3$ in $\operatorname{diet} / \%$ $\mathrm{Cr} 2 \mathrm{O} 3$ in feces)]

Nutrient digestibility $(\%)=100-[100 \times(\% \mathrm{Cr} 2 \mathrm{O} 3$ in diet $\mathrm{x} \% \mathrm{nu}-$ trient in feces) $/ \%$ Cr2O3 in feces $\mathrm{x} \%$ nutrient in diet)]

All data are shown as means \pm SD and were subjected to one-way ANOVA using SPSS for Windows version 16.0 (Chicago, IL, USA). Duncan new multiple range test was used to test for significant difference of treatment means at level of $\mathrm{P}<0.05$.

\section{Results}

At the end of the trial, survival rates of test fish were in ranges of 90-97\% and were not significantly different among fish fed the control diet of $35 \%$ fishmeal and diets in which fishmeal protein was replaced by yeast-fermented canola meal at ratios of 25,50 and $75 \%(P>0.05)$. In contrast, fish fed the diet in which fishmeal protein was completely replaced rejected the feed and all died within 2 weeks. For growth performance, the results showed that fish fed the diet in which $75 \%$ of fishmeal protein was replaced had significantly lower final mean weight
$(\mathrm{P}<0.01)$ compared with fish fed the other diets. These differences were clearly noticeable after 30 days of the culture period (Figure 1).

For all test diets except that with $100 \%$ replacement, feed intake of the test fish was not significantly different $(\mathrm{P}>0.05)$, but $75 \%$ replacement of fishmeal protein led to significantly higher feed conversion ratio and lower protein efficiency ratio $(\mathrm{P}<0.01)$ compared with the other diets (Figure 2). This seemed to be related significantly to the lower digestibility of dry matter, crude protein and ash (Figure 3).

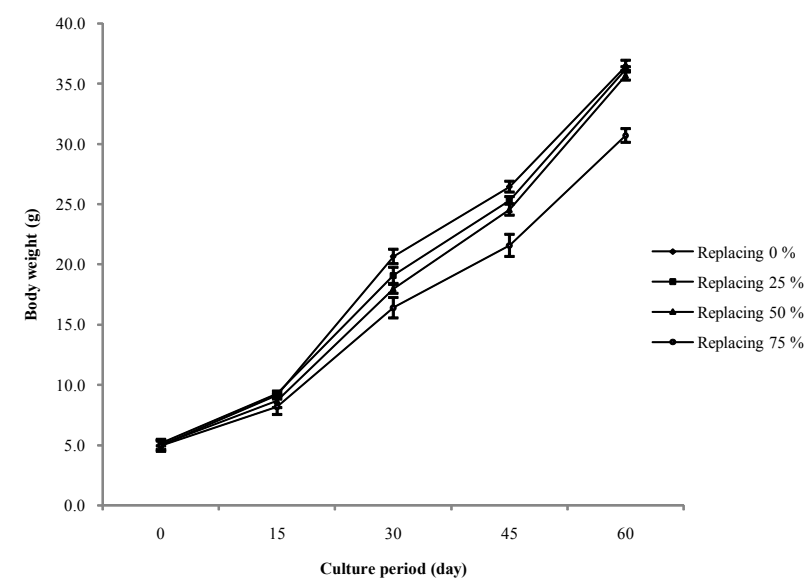

Figure 1: Mean body weight of test Asian sea bass measured every 15 days (g).

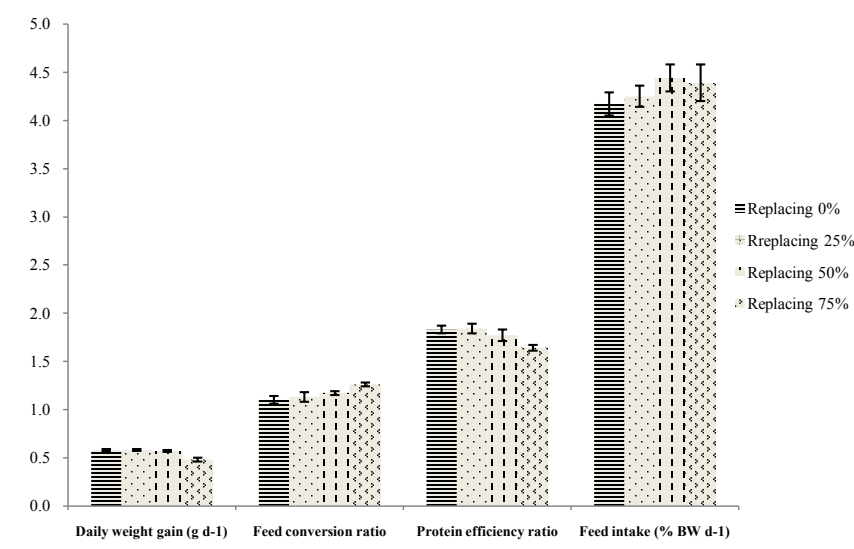

Figure 2: Daily weight gains and feed utilisation of Asian sea bass fed the test diets.

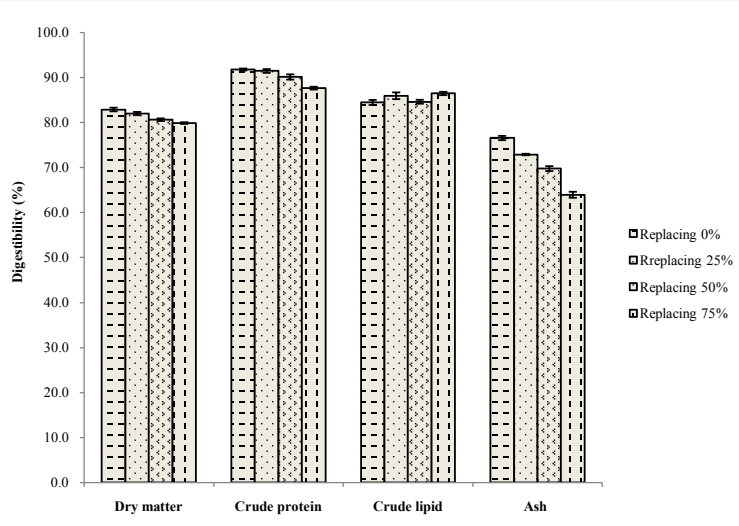

Figure 3: Nutrient digestibility of Asian sea bass fed the test diets (\%). 
Differences of growth were not statistically significant, but showed a decreasing trend as the level of fishmeal protein replacement increased to 25 and $50 \%$, respectively. Nutrient digestibility and protein efficiency also showed similar trends. In contrast, feed conversion ratio and feed intake were increased.

Table 4 shows whole body proximate and mineral composition of Asian sea bass fed the test diets. There were significant differences in body crude protein, crude lipid and all minerals among fish fed test diets $(\mathrm{P}<0.01)$, and in body ash $(\mathrm{P}<0.05)$. Body crude protein, ash, $\mathrm{Ca}, \mathrm{Mg}, \mathrm{P}$ and $\mathrm{Mn}$ tended to decrease as the level of protein replacement increased from 0 to $50 \%$. In contrast, body crude lipid, Fe, Zn and $\mathrm{Cu}$ tended to increase. However, all these parameters showed opposite trends as ratio of protein replacement increased from 50 to $75 \%$. Determination of $\mathrm{Ca} / \mathrm{P}$ ratio showed no significant differences among fish fed all the different test diets $(\mathrm{P}>0.05)$.

Figure 4 shows the nutrient utilization by Asian sea bass fed the test diets. There were significant differences among fish fed the control diet and diets in which fishmeal protein was replaced at levels of 25, 50 and $75 \%$, in the utilization of most nutrients $(\mathrm{P}<0.01)$, including ash, $\mathrm{P}$ and $\mathrm{Mn}(\mathrm{P}<0.05)$. Utilization of crude protein, $\mathrm{Ca}, \mathrm{Mg}, \mathrm{P}$ tended to decrease as the level of protein replacement increased. In contrast, crude lipid, ash, $\mathrm{Fe}, \mathrm{Cu}$ and $\mathrm{Mn}$ tended to increase.

\section{Discussion}

A typical diet for Asian sea bass contains 35\% fishmeal. This study

\begin{tabular}{|l|l|l|l|l|c|}
\hline \multirow{2}{*}{} & \multicolumn{3}{|l}{$\%$ Replacing fishmeal protein } & \multicolumn{1}{l|}{ P } \\
\cline { 2 - 6 } & \multicolumn{1}{|c}{0} & \multicolumn{1}{|l}{25} & \multicolumn{1}{l|}{50} & \multicolumn{1}{l|}{75} & \\
\hline Crude protein & $571.53 \pm 1.72^{\mathrm{b}}$ & $582.17 \pm 2.78^{\mathrm{a}}$ & $566.43 \pm 3.61^{\mathrm{b}}$ & $566.27 \pm 3.97^{\mathrm{b}}$ & 0.001 \\
\hline Crude lipid & $249.90 \pm 1.73^{\mathrm{c}}$ & $246.23 \pm 4.02^{\mathrm{c}}$ & $287.57 \pm 3.17^{\mathrm{a}}$ & $281.23 \pm 1.08^{\mathrm{b}}$ & 0.000 \\
\hline Ash & $138.23 \pm 2.58^{\mathrm{ab}}$ & $135.53 \pm 3.02^{\mathrm{b}}$ & $134.83 \pm 2.75^{\mathrm{b}}$ & $143.57 \pm 3.60^{\mathrm{a}}$ & 0.028 \\
\hline $\mathrm{Ca}$ & $46.33 \pm 0.37^{\mathrm{b}}$ & $46.90 \pm 0.70^{\mathrm{b}}$ & $45.83 \pm 0.60^{\mathrm{b}}$ & $50.93 \pm 0.61^{\mathrm{a}}$ & 0.000 \\
\hline $\mathrm{Mg}$ & $1.60 \pm 0.00^{\mathrm{b}}$ & $1.63 \pm 0.06^{\mathrm{b}}$ & $1.47 \pm 0.06^{\mathrm{c}}$ & $1.83 \pm 0.06^{\mathrm{a}}$ & 0.000 \\
\hline $\mathrm{P}$ & $23.43 \pm 0.30^{\mathrm{b}}$ & $23.80 \pm 0.26^{\mathrm{b}}$ & $22.80 \pm 0.26^{\mathrm{c}}$ & $25.37 \pm 0.20^{\mathrm{a}}$ & 0.000 \\
\hline $\mathrm{Fe}$ & $0.40 \pm 0.04^{\mathrm{d}}$ & $0.66 \pm 0.07^{\mathrm{c}}$ & $1.29 \pm 0.09^{\mathrm{a}}$ & $0.79 \pm 0.04^{\mathrm{b}}$ & 0.000 \\
\hline $\mathrm{Zn}$ & $0.55 \pm 0.02^{\mathrm{c}}$ & $0.72 \pm 0.03^{\mathrm{a}}$ & $0.63 \pm 0.02^{\mathrm{b}}$ & $0.66 \pm 0.02^{\mathrm{b}}$ & 0.000 \\
\hline $\mathrm{Cu}$ & $0.083 \pm 0.006^{\mathrm{c}}$ & $0.060 \pm 0.000^{\mathrm{d}}$ & $0.010 \pm 0.000^{\mathrm{a}}$ & $0.090 \pm 0.000^{\mathrm{b}}$ & 0.000 \\
\hline $\mathrm{Mn}$ & $0.050 \pm 0.000^{\mathrm{b}}$ & $0.060 \pm 0.000^{\mathrm{a}}$ & $0.040 \pm 0.000^{\mathrm{c}}$ & $0.053 \pm 0.0006^{\mathrm{b}}$ & 0.000 \\
\hline $\mathrm{Ca} / \mathrm{P}$ ratio & $1.98 \pm 0.03^{\mathrm{a}}$ & $1.97 \pm 0.01^{\mathrm{a}}$ & $2.01 \pm 0.01^{\mathrm{a}}$ & $2.01 \pm 0.03^{\mathrm{a}}$ & 0.141 \\
\hline
\end{tabular}

* Means with same superscript in each row are insignificantly different $(P>0.05)$

Table 4: Whole body proximate composition and minerals of Asian sea bass fed test diets (g Kg-1, dry basis). *

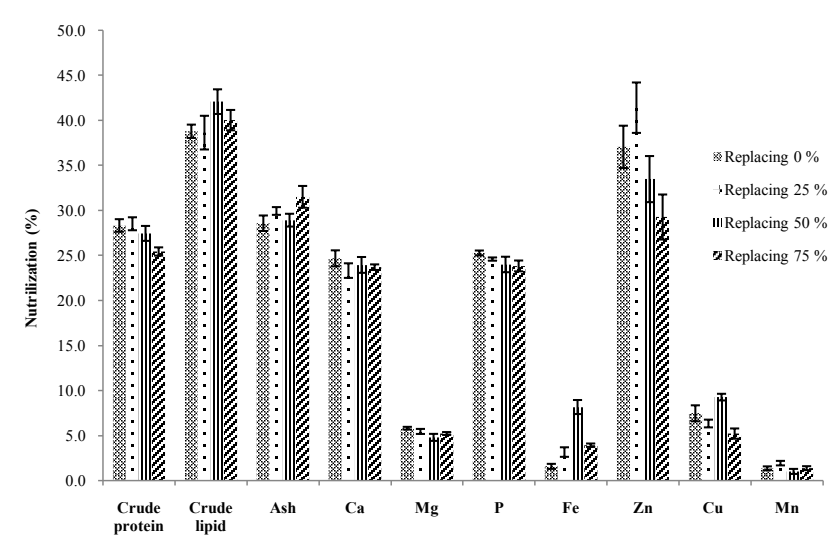

Figure 4: Nutrient utilisation of Asian sea bass fed the test diets (\%). showed that $50 \%$ of the fishmeal could be replaced by yeast-fermented canola meal without overall impact on growth. However, fish growth showed a decreasing trend as the level of fishmeal protein replacement was increased further. The impact of $75 \%$ replacement on growth was clear, so practical replacement of fishmeal protein by $75 \%$ could not be achieved. The reduction of growth found in this study was similar to that seen when soybean meal was used to replace fishmeal for Asian sea bass, cobia and Nile tilapia or when yeast-fermented soybean meal was used for black sea bream [15,24-26]. A cause is the lower digestibility of many components, especially protein and ash (mineral). The increased dietary phytic acid might also be a cause. Free phytic acid can chelate with mineral to form phytate in the small intestine (under neutral or alkaline conditions). A further complex, phytin, can be formed when phytate binds with protein, amino acid or protease enzymes [27].

For these reasons, this ANF could be responsible for the lower digestibility of both protein and ash (mineral) observed in this study. A previous study showed similar lower nutrient digestibility to support this assumption; increasing replacement of fishmeal by yeast-fermented soybean meal for black sea bream results in lower digestibility of dry matter and crude protein. These effects seemed to relate to increasing dietary phytic acid [26].

Another study clearly shows that using phytase to reduce phytin levels soy protein concentrate increases protein digestibility by Atlantic salmon [28]. Previous studies also show that reducing dietary phytic acid by treatment with phytase increases growth and feed efficiency in rainbow trout, Nile tilapia and Atlantic salmon [28-32]. In addition, the effects of increasing dietary phytic acid in fish seen in the present study might be interpreted by lower utilization of body nutrients, particularly crude protein, $\mathrm{Ca}, \mathrm{Mg}$ and $\mathrm{P}$. In rainbow trout, body protein, $\mathrm{Ca}, \mathrm{Mg} \mathrm{P}$ and $\mathrm{Zn}$ and their utilization increased as fish were fed a diet containing soy concentrate dephytinized with phytase [29]. This procedure also increases body ash, $\mathrm{Ca}$ and $\mathrm{Mg}$ in Atlantic salmon fed a diet containing treated soy protein concentrate [28].

In contrast to their low utilization, body $\mathrm{Ca}$ and $\mathrm{P}$ increased as fish were fed a diet in which $75 \%$ of fishmeal protein was replaced. A reason could be that the fish increased their feed intake to compensate for lower digestibility and utilization. Furthermore, the fish body might adapt the efficiency of deposition of both minerals to balance the body $\mathrm{Ca} / \mathrm{P}$ ratio $[28]$.

In addition to lower digestibility, a reduction in body ash seemed to be related to lower dietary ash as the level of protein replacement increased. This trend has also been observed with Nile tilapia and rainbow trout fed a diet in which soybean meal was used to replace fishmeal $[25,33]$. Meanwhile, body lipid and utilization in Asian sea bass showed an increasing trend with increasing level of fishmeal protein replacement. This agreed with a previous study on the use of canola meal in red sea bream [34]. As the proportions of body crude protein and ash are reduced, the percentage of body crude lipid increases.

Increasing the level of fishmeal protein replacement from 0 to $75 \%$ seemed to increase feed intake by the fish. This might be related to the lower digestibility of nutrients described above. This trend was also seen with Atlantic salmon fed a diet containing undephytinized soy protein concentrate compared with the dephytinized product [28]. Meanwhile, increasing the ratio of fishmeal protein replacement to $100 \%$ (i.e. $0 \%$ fishmeal) led to complete diet rejection, probably because of lack of feeding attractants [35]. However, this study showed the possibility of reducing dietary fishmeal to below $10 \%$, as fish still accepted a diet containing $8.75 \%$ fishmeal (replacement level 75\%). This result 
Citation: Plaipetch P, Yakupitiyage A (2012) Use of Yeast-Fermented Canola Meal to Replace Fishmeal in the Diet of Asian Sea Bass Lates Calcarifer (Bloch, 1790). J Aquac Res Development 3:125 doi:10.4172/2155-9546.1000125

was similar to that seen with juvenile Asian sea bass that accepted a diet containing $11 \%$ fishmeal [8]. The present study suggests that complete replacement of fishmeal by other sources in the diet of Asian sea bass is possible. Integration of an alternative protein source with an attractant, e.g. betaine, might be an interesting approach. A study shows that this attractant can increase feed intake and improve growth of rainbow trout fed a plant-based diet [35].

In conclusion, replacing fishmeal by a high level of yeast-fermented canola meal caused reduction of growth, feed utilization, nutrient digestibility, body crude protein, ash, $\mathrm{Ca}, \mathrm{Mg}, \mathrm{P}$ and their utilization. This seemed to be related to increasing dietary phytic acid. However, a 50\% replacement level did not affect overall growth. This study also showed the possibility of reducing dietary fishmeal to below $10 \%$, as fish accepted a diet containing only $8.75 \%$ fishmeal.

\section{Acknowledgement}

This study was supported by thesis funding from the Asian Institute of Technology, Thailand. The authors greatly appreciate the help of staff of the Coastal Aquatic Feed Research Institute, Department of Fisheries, Chonburi, Thailand who helped to analyze minerals. Also an author thanks $\mathrm{Dr}$. Goerge Britton for his edition of some sentences and grammar.

\section{References}

1. EGlencross B (2006) The nutritional management of barramundi, Lates calcarifer - a review. Aquac Nutr 12: 291-309.

2. Peet C (2006) Barramundi seafood watch report. Monterey Bay Aquarium, CA USA.

3. Williams KC, Rimmer MA (2005) The future of feeds and feeding of marine finfish in the Asia-Pacific region: the need to develop alternative aquaculture feeds. Regional workshop on low value/"trash fish" in the Asia-Pacific region, June 7-9 2005, Hanoi, Vietnam.

4. Tacon AGJ, Metian M (2008) Global overview on the use of fish meal and fish oil in industrially compounded aquafeeds: trends and future prospects. Aquaculture 285: 146-158.

5. Naylor RL, Goldburg RJ, Primavera JH, Kautsky N, Beveridge MC, et al. (2000) Effect of aquaculture on world fish supplies. Nature 405: 1017-1024

6. Gatlin III DM, Barrows FT, Brown P, Dabrowski K, Gaylord TG, et al. (2007) Expanding the utilization of sustainable plant products in aquafeeds: a review. Aquac Res 38: 551-579.

7. Williams KC, Barlow CG, Rodgers LJ, Ruscoe I (2003) Potential of meat meal to replace fishmeal in extruded dry diets for barramundi, Lates calcarife (Bloch): I Growth performance. Aquac Res 34: 23-32.

8. Glencross BD, Rutherford N, Jones B (2011) Evaluating options for fishmea replacement in diets for juvenile barramundi (Lates calcarifer). Aquac Nutr 17: e722-e732.

9. Higgs DA, Dosanjh BS, Prendegast AF, Beams RM, Hardy RW, et al. (1995) Use of rapeseed/canola protein products in finfish diets. In: Nutrition and utilization technology in aquaculture (Lim CE, Sessa DJ, edn). AOCS Press, Champaign, IL, USA

10. Francis G, Makkar HPS, Becker K (2001) Antinutritional factors present in plant-derived alternate fish feed ingredients and their effects in fish. Aquaculture 199: 197-227.

11. Oboh G, Akindahunsi AA (2003) Biochemical changes in cassava products (flour \& gari) subjected to Sacchromyces cerevisae solid media fermentation. Food Chem 82: 599-602.

12. Oboh G, Elusiyan CA (2007) Changes in the nutrient and anti-nutrient content of micro-fungi fermented cassava flour produced from low- and medium-cyanide variety of cassava tubers. Afr J Biotechnol 6: 2150-2157.

13. Fauduet H, Coic JP, Lessire M, Quinsac A, Ribaillier D, et al. (1995) Rapeseed meal upgrading-pilot scale preparation of rapeseed meal materials with high or low glucosinolate contents. Anim Feed Sci Technol 56: 99-109.

14. Vijayakumari K, Pugalenthi M, Vadivel V (2007) Effect of soaking and hydrothermal processing methods on the levels of antinutrients and in vitro protein digestibility of Bauhinia purpurea L. seeds. Food Chem 103: 968-975.
15. Boonyaratpalin M, Suraneiranat $P$, Tunpibal T (1998) Replacement of fishmeal with various types of soybean products in the diets for the Asian seabass, Lates calcarifer. Aquaculture 161: 67-78.

16. Yabaya A, Akinyanju JA, Jatou ED (2009) Yeast enrichment of soybean cake. World J Dairy \& Food Sci 4: 141-144.

17. Cho CY, Slinger SJ, Baley HS (1982) Bioenergetics of salmonid fishes: Energy intake, Expenditure and Productivity. Comp Biochem Physiol 73(B): 25-41.

18. Association of Official Analytical Chemists (1990) Official Methods of Analysis of the Association of Official Analytical Chemists, 15th edn, Arlington, VA, USA

19. Association of Official Analytical Chemists (2005) Official Methods of Analysis of the Association of Official Analytical Chemists, 18th edn. Gaithersburg, USA

20. Boonpluem N (2007) Evaluation of nutritional values and anti-nutritional factors in wastes from passion fruit juice production. Chiang Mai University, Thailand.

21. Young $L$ (1936) The determination of phytic acid. Biochem J 30: 252-257.

22. Bell JM (1984) Nutrients and toxicants in rapeseed meal: a review. J Anim Sc 58: 996-1010.

23. Cho CY, Slinger SJ (1979) Apparent digestibility measurement in feedstuffs fo rainbow trout. Proceedings of the world symposium on finfish nutrition and fishfeed technology.

24. Chou RL, Her BY, Su MS, Hwang G, Wu YH, et al. (2004) Substituting fish mea with soybean meal in diets of juvenile cobia Rachycentron canadum. Aquaculture 229: $325-333$

25. Koumi AR, Koffi KM, Atsé BC, Kouame LP (2011) Growth, feed efficiency and carcass mineral composition of Heterobranchus longifilis, Oreochromis niloticus and Sarotherodon melanotheron juveniles fed different dietary levels of soybean meal-based diets. Afr J Biotechnol 10: 14990-14998.

26. Zhou F, Song W, Shao Q, Peng X, Xiao J, et al. (2011) Partial replacement of fishmeal by fermented soybean meal in diets for black sea bream, Acanthopagrus schlegelii, juveniles. J World Aquac Soc 42: 184-197.

27. Kornegay ET (2001) Digestion of phosphorus and other nutrients: the role of phytases and factors influencing their activity. In: Enzyme in farmed animal nutrition (Bedford MR, Partridge GG, edn.). CABI Publishing, Wallingford, UK.

28. Storebakken T, Shearer KD, Roem AJ (1998) Availability of protein, phosphorus and other elements in fish meal, soy-protein concentrate and phytase-treated soy-protein-concentrate-based diets to Atlantic salmon, Salmo salar. Aquaculture 161: $365-379$

29. Vielma J, Ruohonen K, Peisker M (2002) Dephytinization of two soy proteins increases phosphorus and protein utilization by rainbow trout, Oncorhynchus mykiss. Aquaculture 204: 145-156.

30. Liebert F, Portz L (2005) Nutrient utilization of Nile tilapia Oreochromis niloticus fed plant based low phosphorus diets supplemented with graded levels of different sources of microbial phytase. Aquaculture 248: 111-119.

31. Cao L, Yang Y, Wang WM, Yakupitiyage A, Yuan DR, et al. (2009) Effects of pretreatment with microbial phytase on phosphorous utilization and growth performance of Nile tilapia (Oreochromis niloticus). Aquac Nutr 14: 99-109.

32. Abo-State HA, Tahoun AM, Hammouda YA (2009) Effect of replacement of soy bean meal by DDGS combined with commercial phytase on Nile tilapia (Ore ochromis niloticus) fingerlings growth performance and feed utilization. AmerEurasian J Agri \& Environsci 5: 473-479.

33. Tiril SU, Alagil F, Yagci FB, Aral O (2008) Effects of betaine supplementation in plant protein based diets on feed intake and growth performance in rainbow trout (Oncorhynchus mykiss). Isr J Aquacult-Bamid 60: 57-64.

34. Glencross BD (2003) Pilot assessment of the potential for canola meal and oil use in aquaculture feeds, final report for the grains research and development corporation no. 5. Department of Fisheries, Western Australia.

35. National Research Council (1993) Nutrient requirements of fish. National Academy Press, Washington DC, USA. 